\title{
HOW BROAD A MEANING CAN "CAPITAL" AGQUIRE? TOWARDS THE RIGOROUS COMPREHENSION OF CAPITAL
}

\author{
Balázs István TóTH ${ }^{\mathrm{a} *}$ \\ a) University of Sopron Alexandre Lamfalussy, Faculty of Economics, \\ Sopron, Hungary
}

Please cite this article as:

Article History:

Tóth, B.I., 2020. How broad a meaning can "capital" acquire? Towards the rigorous comprehension of capital. Review of Economic Studies and Research Virgil Madgearu, 13(2), pp.169-197.

doi: 10.24193/RVM.2020.13.67.

\begin{abstract}
This paper explores some of the recent challenges concerning the contemporary meaning of capital by reconsidering the role of alternative forms of capital in scientific progress. The first aim of the study is to review the main contradictions in the notion of capital, with special regard to economics and sociology. Second, it is aimed at highlighting the genesis of and the popular literature on the alternative forms of capital. Besides, the paper reassesses the role of the state-of-the-art notions and interpretations related to the subject matter. The study argues that the understanding of capital should be defended from further atomization, and calls for more clarity and consistency between disciplines and in the usage of the term capital. Accordingly, some propositions are provided that may lead scholars to outline the rigorous comprehension of capital.
\end{abstract}

Key words: meaning of capital; forms of capital; economics and sociology; rigorous comprehension of capital; scientific progress

JEL Classification: A12; B5O; E22; Z13

(C) 2020 Alma Mater Publishing House. All rights reserved.

* Corresponding author. E-mail address: toth.balazs.istvan@uni-sopron.hu. 
Review of Economic Studies and Research Virgil Madgearu, 202O, 13(2)

\section{References:}

1. Adler, P.S. and Kwon, S.W., 200o. Social Capital: The Good, the Bad, and the Ugly. In: E.L. Lesser, ed., 2000. Knowledge and Social Capital: Foundations and Applications. Boston: ButterworthHeinemann. pp.89-115.

2. Ahmad, Y.J., El Serafy, S. and Lutz, E., 1989. Environmental Accounting for Sustainable Development. Washington D.C.: The World Bank.

3. Anheier, H.K., Gerhards, J. and Romo, F.P., 1995. Forms of Capital and Social Structure in Cultural Fields: Examining Bourdieu's Social Topography. American Journal of Sociology, 100(4), pp.859-903.

4. Arrow, K.J., 1962. The Economic Implications of Learning by Doing. The Review of Economic Studies, 29(3), pp.155-173. https://doi.org/10.2307/2295952.

5. Arrow, K.J., 1999. Observations on Social Capital. In: P. Dasgupta and I. Serageldin, eds. 1999. Social Capital: A Multifaceted Perspective. Washington D.C.: The World Bank. pp.3-5.

6. Babbie, E., 1979. The Practice of Social Research. Belmont: Wadsworth.

7. Becker, G.S., 1962. Investment in Human Capital: A Theoretical Analysis. Journal of Political Economy, 70(5), pp.9-49.

8. Bliss, C.J., 1975. Capital Theory and the Distribution of Income. Amsterdam: North Holland.

9. Booth, J.A. and Richard, P.B., 1998. Civil Society, Political Capital and Democratization in Central America. The Journal of Politics, 60(3), pp.780-80o. https://doi.org/10.2307/2647648.

10. Bourdieu, P. and Passeron, J.C., 1970. La reproduction: Éléments pour une théorie du système d'enseignment. Paris: Minuit.

11. Bourdieu, P., 1986 [1983]. The Forms of Capital. In: J.E. Richardson, ed. 1986[1983]. Handbook of Theory of Research for the Sociology of Education. Westport: Greenwood. pp.241-258.

12. Bourdieu, P., 1987. Choses dites. Paris: Minuit.

13. Böhm-Bawerk, E.v., 1921 [1884]. Kapital und Kapitalzins: Geschichte und Kritik der Kapitalzins-Theorieen. Innsbruck: Verlag der Wagner'schen Universitäts-buchhandlung. 
Tóth, How Broad a Meaning Can "Capital” AcQuire?...

14. Böhm-Bawerk, E.v. 1930 [1888]. The Positive Theory of Capital. New York: G.E. Strechert\&Co.

15. Braun, E., 2017. The Theory of Capital in the Theory of Capitalism. Journal of Institutional Economics, 13(2), pp.305-325. https:// doi.org/10.1017/S1744137416000394.

16. Brooking, A., 1996. Intellectual Capital: Core Asset for the Third Millennium Enterprise. London: International Thomson Business Press.

17. Burmeister, E., 2000. The Capital Theory Controversy. In: H.D. Kurz, ed. 2000. Critical Essays of Piero Sraffa's Legacy in Economics. Cambridge: University Press, pp.305-314.

18. Burt, R., 1992. Structural Holes: The Social Structure of Competition. Cambridge, London: Harvard University Press.

19. Camagni, R., 2008. Regional Competitiveness: Towards a Concept of Territorial Capital. In: R. Capello, R. Camagni, B. Chizzolini and U. Fratesi, eds. 2008. Modelling Regional Scenarios for the Enlarged Europe. European Competitiveness and Global Strategies. Berlin, Heidelberg: Springer. pp.33-46.

20. Cannan, E., 1921. Early History of the Term Capital. The Quarterly Journal of Economics, 35(3), pp.469-481.

21. Cassel, G., 1925. Fundamental thoughts in economics. London: Ernest Benn.

22. Caton, C. and Shell, K., 1971. An Exercise in the Theory of Heterogeneous Capital Accumulation. The Review of Economic Studies, 38(1), pp.13-22. https://doi.org/10.2307/2296618.

23. Clark, J.B., 1887. Christianity and Modern Economics. New Englander and Yale Review, XI(XLVII), pp.50-59.

24. Clark, J.B., 1908. The Distribution of Wealth: A Theory of Wages, Interest and Profits. New York, London: Macmillan\&Co.

25. Coleman, J.S., 1988. Social Capital in the Creation of Human Capital. American Journal of Sociology, 94(Supplement), pp.95-120.

26. Combe, G., 1841. Notes on the United States of North America, during a phrenological visit: in 1938-9-40. Vol. I. Edinburgh: Maclachlan, Stewart\&Co.

27. Costanza, R. and Daly, H.E., 1992. Natural Capital and Sustainable Development. Conservation Biology, 6(1), pp.37-46.

28. Dasgupta, P. and Serageldin, I., 1999. Social Capital: AMultifaceted Perspective. Washington D.C.: The World Bank. 
Review of Economic Studies and Research Virgil Madgearu, 2020, 13(2)

29. De Soto, H., 2001. The Mystery of Capital: Why Capitalism Triumphs in the West and Fails Everywhere Else. London: Black Swan.

30. Deth, J.W.v., 2003. Measuring Social Capital: Orthodoxies and Continuing Controversies. International Journal of Social Research Methodology, 6(1), pp.79-92. https://doi. org/10.1080/13645570305057.

31. Di Maggio, P. and Mohr, J., 1985. Cultural Capital, Educational Attainment, and Marital Selection. American Journal of Sociology, 90(6), pp.1231-1261.

32. Edvinsson, L. and Malone, M.S., 1997. Intellectual Capital: The Proven Way to Establish Your Company's Real Value by Measuring Its Hidden Values. London: Piatkus.

33. Elster, J., 1997. More than Enough. The University of Chicago Law Review, 64(2), pp.749-764.

34. Fetter, F.A., 1900. Recent Discussions of the Capital Concept. The Quarterly Journal of Economics, 15(1), pp.1-45.

35. Fetter, F.A., 1937. Reformulation of the Concepts of Capital and Income in Economics and Accounting. The Accounting Review, 12(1), pp.3-12.

36. Firth, R., 1964. Capital, Saving and Credit in Peasant Societies: A Viewpoint from Economic Anthropology. In: Firth, R. and Yamey, B.S., eds. 1964. Capital, Saving and Credit in Peasant Societies: Studies from Asia, Oceania, The Caribbean and Middle America, London: George Allen\&Unwin. pp.15-34.

37. Flap, H.D. and De Graaf, N.D., 1986. Social Capital and Attained Occupational Status. The Netherlands Journal of Sociology, 22, pp.145-161.

38. Florida, R., 2002. The Rise of Creative Class. New York: Basic Books.

39. Fukuyama, F., 1995. Trust: The Social Virtues and The Creation of Prosperity. New York: Free Press.

40. Fukuyama, F. 2000. Social Capital and Civil Society. IMF Working Paper 74. International Monetary Fund.

41. Galbraith, J.K., 1967. The New Industrial State. Princeton: University Press.

42. Giddens, A., 2009. Sociology. Cambridge: Polity Press.

43. Granovetter, M.S., 1973. The Strength of Weak Ties. American Journal of Sociology, 78(6), pp.1360-1380. 
Tóth, How Broad a Meaning Can "Capital” AcQuire?...

44. Hahn, F.H., 1966. Equilibrium Dynamics with Heterogeneous Capital Goods. The Quarterly Journal of Economics, 80(4), pp.633-646.

45. Hamel, G. and Prahalad, C.K., 1990. The Core Competence of the Corporation. Harvard Business Review, 68(3), pp.79-91.

46. Hanifan, L.J., 1916. The Rural School Community Centre. Annals of the American Academy of Political and Social Science, 67(September), pp.130-138.

47. Harcourt, G.C., 1969. Some Cambridge Controversies in the Theory of Capital. Journal of Economic Literature, 7(2), pp.369-405.

48. Hausman, D.M., 1981. Capital, Profits and Prices: An Essay in the Philosophy of Economics. New York: Columbia University Press.

49. Helm, D., 2015. Natural Capital: Valuing the Planet. New Haven, London: Yale University Press.

50. Hennings, K.H., 1987. Capital as a Factor of Production. In: J. Eatwell, M. Milgate and P. Newman, eds. 1987. New Palgrave: A Dictionary of Economics. London: Macmillan. pp.327-333.

51. Herfindahl, O.C. and Kneese, A.V., 1974. Natural Theory of Natural Resources. Columbus: Charles E. Merill.

52. Heyne, P., 1997. The Economic Way of Thinking. Upper Saddle River: Prentice Hall.

53. Hicks, J., 1974. Capital Controversies: Ancient and Modern. The American Economic Review, 64(2), pp.307-316.

54. Hicks, J., 1981. Wealth and Welfare: Collected Essays in Economic Theory. Vol. I. Cambridge: Harvard University Press.

55. Hirshleifer, J., 1970. Investment, Interest and Capital. Englewood Cliffs: Prentice Hall.

56. Hodgson, G.M., 2014. What is capital? Economists and sociologists have changed its meaning: should it be changed back? Cambridge Journal of Economics, 38(5), pp.1063-1086. https://doi. org/10.1093/cje/beuo13.

57. Hotelling, H., 1931. The Economics of Exhaustible Resources. Journal of Political Economy, 39(2), pp.137-175.

58. Huggins, R. and Izushi, H., 2008. Benchmarking the knowledge competitiveness of the globe's high performing regions: A review of the World Knowledge Competitiveness Index. Competitiveness Review: An International Business Journal, 18(1-2), pp.70-86. https://doi.org/10.1108/10595420810874619. 
Review of Economic Studies and Research Virgil Madgearu, 202O, 13(2)

59. Jones, E., 1849. The Land Monopoly, the Suffering and Demoralization Caused by It; and the Justice \& Expediency of its Abolition. London: Chas. Fox.

6o. Kirzner, I.M., 1976. The Theory of Capital. In: E.G. Dolan, ed. 1976. The Foundations of Modern Austrian Economics. Kansas City: Sheed\&Ward. pp.133-151.

61. Kitson, M., Martin, R. and Tyler,P., 2004. Regional Competitiveness: An Elusive yet Key Concept? Regional Studies, 38(9), pp.991-999. https://doi.org/10.1080/0034340042000320816.

62. Klimoski, R., 1991. Theory Presentation in Human Resource Management. Human Resource Management Review, 1(4), pp.253-271.

63. Lachmann, L.M., 1956. Capital and Its Structure. Kansas City: Sheed Andrews and McMeel.

64. LEADER European Observatory (LEADER EO), 1999. Territorial competitiveness. Creating a territorial development strategy in light of the LEADER experience. Part 1. Brussels: LEADER European Observatory.

65. Lin, N., 2001. Social Capital: A Theory of Social Structure and Action. Cambridge: University Press.

66. List, F., 1841. Das nationale System der politischen Ökonomie. Stuttgart: Cotta'schen Verlag.

67. Lucas, R.E., 1988. On the Mechanics of Economic Development. Journal of Monetary Economics, 22(1), pp.3-42.

68. Marshall, A., 1920. Principles of Economics: An Introductory Volume. London: Macmillan.

69. Marx, K., 1867. Das Kapital: Kritik der politischen Ökonomie. Hamburg: Otto Meissner.

70. McCann, P., 2006. Observational Equivalence? Regional Studies and Regional Science. Regional Studies, 41(9), pp.1209-1222. https://doi.org/10.1080/00343400701624494.

71. McCann, P., 2013. Modern Urban and Regional Economics. Oxford: University Press.

72. Mintzberg, H., Ahlstrand, B. and Lampel, J., 1998. Strategy Safari. New York: Free Press.

73. Missemer, A., 2018. Natural Capital as an Economic Concept, History and Contemporary Issues. Ecological Economics, 143, pp.90-96. https://doi.org/10.1016/j.ecolecon.2017.07.011. 
Tóth, How Broad a MeAning CAN “CAPITAL” ACQUiRe?...

74. Mitchell Innes, A., 1914. The Credit Theory of Money. The Banking Law Journal, 31(December-January), pp.151-168.

75. Müller, A., 1809. Die Elemente der Staatskunst. Berlin: J.D. Sander.

76. O’Sullivan, M.A., 2016. A Confusion of Capital in the United States. In: P. Hudson and K. Tribe, eds. 2016. The Contradictions of Capital in the Twenty-First Century: The Piketty Opportunity. Newcastle upon Tyne: Agenda Publishing. pp.131-165.

77. Organisation for Economic Co-operation and Development (OECD), 2001a. The Well-Being of Nations: The Role of Human and Social Capital. Paris: OECD.

78. Organisation for Economic Co-operation and Development (OECD), 2001b. Territorial Outlook. Paris: OECD.

79. Pearce, D.W., 1992. The MIT Dictionary of Modern Economics. Cambridge: MIT Press.

80. Pearce, D.W., Barbier, E. and Markandya, A., 1990. Sustainable Development: Economics and Environment in the Third World. Aldershot: Edward Elgar.

81. Pearce, D.W. and Turner, R.K., 1990. Economics of Natural Resources and the Environment. New York: Harvester Wheatsheaf.

82. Pigou, A.C., 1928. A Study in Public Finance. London: Macmillan.

83. Piketty, T., 2014. Capital in the Twenty-First Century. Cambridge, London: Belknap Press.

84. Poole, M.S. and Van de Ven, A.H., 1989. Using Paradox to Build Management and Organization Theories. Academy Management Review, 14(4), pp.562-578.

85. Putnam, R.D., 1993. Making Democracy Work: Civic Transitions in Modern Italy. Princeton: University Press.

86. Ricardo, D., 1817. On the Principles of Political Economy and Taxation. London: John Murray.

87. Robison, L.J., Schmid, A.A. and Siles, M.E., 2002. Is Social Capital Really Capital? Review of Social Economy, 6o(1), pp.1-21.

88. Romer, P.M., 1986. Increasing Returns and Long-Run Growth. Journal of Political Economy, 94(5), pp.1002-1037.

89. Roos, G. and Roos, J., 1997. Measuring your company's intellectual performance. Long Range Planning, 30(3), pp.413-426.

90. Rutherford, D., 2002. Routledge Dictionary of Economics. London, New York: Routledge. 
91. Samuelson, P.A., 1962. Parable and Realism in Capital Theory: The Surrogate Production Function. Review of Economic Studies, 29(3), pp.193-206.

92. Savage, M., Barlow, J., Dickens, P. and Fielding, T., 1992. Property, Bureaucracy and Culture: Middle Class Formation in Contemporary Britain. London, New York: Routledge.

93. Schlözer, C.v., 1805. Anfangsgründe der Staatswirtschaft oder die Lehre von dem Nationalreichthume. Riga: C.J.G. Hartman.

94. Schultz, T.W., 1959. Investment in Man: An Economist's View. Social Service Review, 33(2), pp.109-117.

95. Scrivens, K. and Smith, C., 2013. Four Interpretations of Social Capital. OECD Statistics Working Papers 06. Paris: OECD.

96. Skinner, Q., 1969. Meaning and Understanding in the History of Ideas. History and Theory, 8(1), pp.3-53.

97. Smith, A., 1776. An Inquiry into the Nature and Causes of the Wealth of Nations. London: W.Strahan, T.Cadell.

98. Solow, R.M., 1956. A Contribution to the Theory of Economic Growth. The Quarterly Journal of Economics, 70(1), pp.65-94.

99. Solow, R.M., 1963. Capital Theory and the Rate of Return. North Holland: Amsterdam.

100. Solow, R.M., 1974. Richard T. Ely Lecture: The Economics of Resources or the Resources of Economics. The American Economic Review, 64(2), pp.1-14.

101. Solow, R.M., 1999. Notes on Social Capital and Economic Performance. In: P. Dasgupta and I. Serageldin, eds. 1999. Social Capital: A Multifaceted Perspective. Washington D.C.: The World Bank. pp.6-10.

102. Sørensen, E. and Torfing, J., 2003. Network Politics, Political Capital and Democracy. International Journal of Public Administration, 26(6), pp.609-634. https://doi.org/10.1081/ PAD-120019238.

103. Špaček, O., 2017. Measuring Cultural Capital: Taste and Legitimate Culture of Czech Youth. Sociological Research Online, 22(1), Article 6. Available at: <http://www.socresonline.org.uk/22/1/6. html $>$ [Accessed 1 November 2019].

104. Stewart, T.A., 1991. Brainpower: Intellectual Capital is Becoming Corporate America's Most Valuable Asset and Can Be Its Sharpest Competitive Weapon; the Challenge is to Find What You Have and Use It. Fortune, 123(1), pp.44-60. 
Tóth, How Broad a Meaning Can "Capital" Acquire?...

105. Stewart, T.A., 1997. Intellectual Capital: The New Wealth of Organizations. New York: Doubleday.

106. Stigler, G.J., 1955. The Nature and Role of Originality in Scientific Progress. Economica, 22(November), pp.293-302.

107. Stiglitz, J.E., 1974. The Cambridge-Cambridge Controversy in the Theory of Capital; A View for New Haven: A Review Article. Journal of Political Economy, 82(4), pp.893-903.

108. Stiglitz, J.E., 1999. Formal and Informal Institutions. In: P. Dasgupta and I. Serageldin, eds. 1999. Social Capital: A Multifaceted Perspective. Washington D.C.: The World Bank. pp.59-68.

109. Storberg, J., 2002. The Evolution of Capital Theory: A Critique of a Theory of Social Capital and Implications for HRD. Human Resource Development Review, 1(4), pp.468-499. https://doi. org/10.1177/1534484302238437.

110. Svendsen, G.L.H. and Svendsen, G.T., 2003. On the Wealth of Nations: Bourdieueconomics and Social Capital. Theory and Society, 32(5-6), pp.607-637.

111. Thorsby, D., 1999. Cultural Capital.Journal of Cultural Economics, 23(1-2), pp.3-12.

112. Tomer, J., 1999. Social and Organizational Capital. In: P.A. O'Hara, ed. 1999. Encyclopedia of Political Economy, London: Routledge. pp.1049-1051.

113. Tóth, B.I., 2015. Territorial Capital: Theory, Empirics and Critical Remarks. European Planning Studies, 23(7), pp.1327-1344. https://doi.org/10.1080/09654313.2014.928675.

114. Tóth, B.I., 2017. Territorial Capital - a Fuzzy Policy-Driven Concept: Context, Issues, and Perspectives. EUROPA XXI, 33, pp.5-19. https://doi.org/10.7163/Eu21.2017.33.1.

115. Ulibarry, C.A., 2000. Rational Philanthropy and Cultural Capital. Journal of Cultural Economics, 24(2), pp.135-146.

116. United Nations (UN), 2008. Measuring Sustainable Development. New York, Geneva: UN.

117. Uzawa, H., 1965. Optimum Technical Change in An Aggregative Model of Economic Growth. International Economic Review, 6(1), pp.18-31.

118. Victor, P.A., 1991. Indicators of Sustainable Development: Some Lessons from Capital Theory. Ecological Economics, 4(3), pp.191213. 
119. Walras, L., 1874. Éléments d'économie politique pure ou Théorie de la richesse sociale. Lausanne: L. Corbaz\&C ${ }^{\text {ie }}$.

120. Weick, K.E., 1989. Theory Construction as Disciplined Imagination. Academy Management Review, 14(4), pp.516-531.

121. Westlund, H., 2006. Social Capital in the Knowledge Economy: Theory and Empirics. Berlin-Heidelberg-New York: Springer.

122. Wicksell, K., 1938 [1901]. Lectures on Political Economy: General Theory. Vol. I. London: Routledge and Sons.

123. World Bank, 2006. Where is the Wealth of Nations? Measuring Capital for the 21st Century. Washington D.C.: The World Bank. 